Canadian Journal of Higher Education

Revue canadienne d'enseignement supérieur

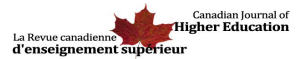

\title{
Academic Drift in Canadian Institutions of Higher Education: Research Mandates, Strategy, and Culture
}

\section{Lane D. Trotter et Amy Mitchell}

Volume 48, numéro 2, 2018

URI : https://id.erudit.org/iderudit/1057105ar

DOI : https://doi.org/10.7202/1057105ar

Aller au sommaire du numéro

\section{Éditeur(s)}

Canadian Society for the Study of Higher Education

ISSN

2293-6602 (numérique)

Découvrir la revue

Citer cet article

Trotter, L. \& Mitchell, A. (2018). Academic Drift in Canadian Institutions of Higher Education: Research Mandates, Strategy, and Culture. Canadian Journal of Higher Education / Revue canadienne d'enseignement supérieur, 48(2), 92-108. https://doi.org/10.7202/1057105ar
Résumé de l'article

À l'instar des établissements d'enseignement supérieur du monde entier, la C.-B. et l'Ontario subissent de plus en plus des pressions démographiques et commerciales qui érodent la différence traditionnelle entre les secteurs universitaire et non universitaire (c.-à-d. les collèges et les instituts). Les éléments clés pour s'assurer que les établissements de ces provinces conservent leur rôle unique et leur différenciation dans un contexte changeant attribuable en partie à leurs gouvernements comprennent les mandats de recherche, la transparence de la gouvernance institutionnelle et des documents stratégiques qui résistent à la dérive universitaire créée par l'isomorphisme institutionnel. Ces gouvernements remanient activement leurs systèmes d'enseignement postsecondaire pour les adapter aux besoins économiques nationaux ou régionaux, en augmentant l'accès, en rationalisant l'obtention d'un diplôme et en répondant aux pressions collectives pour disposer d'une université ou d'un établissement décernant des diplômes. L'analyse de la loi habilitante, des directives gouvernementales en matière de politiques et des documents institutionnels des deux provinces montre que la distinction entre les collèges et les universités s'estompe, de même que les coûts qui y sont associés. 


\title{
Academic Drift in Canadian Institutions of Higher Education: Research Mandates, Strategy, and Culture
}

Lane D. Trotter

Langara College

Amy Mitchell

Fanshawe College

\begin{abstract}
As with higher-education institutions around the world, British Columbia (BC) and Ontario are increasingly faced with demographic and market pressures that erode the traditional difference between the university and nonuniversity sectors (i.e., colleges and institutes). Key components that ensure these provinces' institutions preserve their unique roles and differentiations in a changing context, partially driven by their governments, include research mandates, transparency in institutional governance, and strategic documents that resist the academic drift created by institutional isomorphism. Both governments are actively reshaping their post-secondary systems to align with national or regional economic needs, increasing access, streamlining degree completion, and responding to community pressure to have a university or a degree-granting institution. An analysis of the enabling legislation, government policy directives, and institutional documents of both provinces shows that there is a blurring in the distinction between colleges and universities, and the costs associated with this.
\end{abstract}

\section{Résumé}

À l'instar des établissements d'enseignement supérieur du monde entier, la C.-B. et l'Ontario subissent de plus en plus des pressions démographiques et commerciales qui érodent la différence traditionnelle entre les secteurs 
universitaire et non universitaire (c.-à-d. les collèges et les instituts). Les éléments clés pour s'assurer que les établissements de ces provinces conservent leur rôle unique et leur différenciation dans un contexte changeant attribuable en partie à leurs gouvernements comprennent les mandats de recherche, la transparence de la gouvernance institutionnelle et des documents stratégiques qui résistent à la dérive universitaire créée par l'isomorphisme institutionnel. Ces gouvernements remanient activement leurs systèmes d'enseignement postsecondaire pour les adapter aux besoins économiques nationaux ou régionaux, en augmentant l'accès, en rationalisant l'obtention d'un diplôme et en répondant aux pressions collectives pour disposer d'une université ou d'un établissement décernant des diplômes. L'analyse de la loi habilitante, des directives gouvernementales en matière de politiques et des documents institutionnels des deux provinces montre que la distinction entre les collèges et les universités s'estompe, de même que les coûts qui y sont associés.

\section{Introduction}

Over the last two decades, Canadian provincial governments have increasingly seen the post-secondary system as a tool (Dennison, 2006; Dennison \& Schuetze, 2004). To promote economic competitiveness, they have tried to encourage institutions to deliver programs that meet labour market demands and align research with the needs of industry (Fisher et al., 2014; Shanahan \& Jones, 2007). Governments have attempted to increase access to post-secondary education while maintaining or curbing costs (Marginson, 2002). Given the differences in costs (both in terms of student tuition and operating costs) between the university and non-university sectors, Canadian provincial governments have also increasingly turned to the non-university sector to provide increased access to degrees (Marshall, 2008) and to engage in applied research. The challenge that these developments pose is twofold: first, the universities no longer have a monopoly on degree granting and are now offering more vocationally oriented programs; second, the non-university sector is increasingly hiring $\mathrm{PhD}$-credentialled faculty to deliver applied degree programs and to engage in applied research activity. Both sectors have also become more entrepreneurial. The result is that the historically unique roles of the university and non-university sectors are becoming increasingly blurred which, in turn, threatens their respective roles of driving independent research and serving the needs of local communities.

Under the Canadian constitution, the post-secondary system is the responsibility of the 10 provincial and three territorial governments (Shanahan \& Jones, 2007, p. 32). Each province/territory has its own legislation that defines the roles of universities, colleges, and-in some jurisdictions-institutes. This has resulted in a patchwork of different higher-education structures that are similar but not identical (Dennison \& Schuetze, 2004; Marshall, 2004; Shanahan \& Jones, 2007). For the purposes of this paper, we will refer to the Canadian non-university sector (comprised of community colleges, provincial institutes, and polytechnics that, as in the rest of the Western world, are relatively recent inventions) as colleges, since those are the majority of the non-university institutions in Canada. We will also refer to universities with a historically strong research mandate as traditional universities. Our analysis will look at legislation, government policy directives, and institutional documents to examine the role these play in academic drift and differentiation. 
We have chosen to focus on the British Columbia (BC) and Ontario systems because of the differences in these two provinces' approaches. The two provincial college systems were, for the most part, created in the 1960 s as mechanisms to support economic development by providing access to job training and advanced technical skills (Dennison, 1995; Dennison \& Schuetze, 2004; Hogan \& Trotter, 2013; Jones, 1997; Skolnik, 2006, 2010). In BC, the community colleges also provided access outside the main population centres to the first two years of a university-level education, through an articulated transfer system with the universities (Dennison, 1995; Jones, 2009; MacDonald, 1962; Marshall, 2008). In Ontario, the Colleges of Applied Arts and Technology (CAATs) were created to be very distinct from the universities, and were initially legislatively barred from articulated transfer with Ontario universities and from competition with those universities (Clark, Moran, Skolnik, \& Trick, 2009, p. 9). The role of Ontario colleges thus exists in a binary system, distinct and separate from the universities and with a clear focus on regional economic development and labour market training (Jones, 1997; Skolnik, 2010).

The structures of these provincial higher-education systems are now evolving in the direction of blurring the roles of universities and colleges. These changes can be attributed to a variety of factors (Jones, 2009; Marginson, 2002), but legislation in Ontario to create the Post-Secondary Education Choice and Excellence Act (2000) and to revise the Ontario Colleges of Applied Arts and Technology Act (2002) signalled the government's clear intention to reposition colleges by providing them with limited degree-granting authority. In BC, starting in the late 1980s, five university-colleges were created out of existing colleges as part of the province's strategy to increase access to higher education outside of the lower mainland and Victoria; they were eventually given the right to offer full baccalaureate degrees (Dennison, 2006). In addition, the British Columbia Institute of Technology (BCIT) was given applied master's degree-granting status in 2003 and was designated as a polytechnic in 2005 (Marshall, 2008) under the revised College and Institute Act (1996). As a result of the report entitled Campus 2020 (Plant, 2007), BC created five new teaching universities from three university-colleges, one college, and a provincial institute (Hogan \& Trotter, 2013). Within the amended University Act (1996), the teaching universities have a role different from both their former statuses as colleges or institutes and from the research universities (Fisher et al., 2014, p. 40).

Even more recently, both the $\mathrm{BC}$ and Ontario provincial governments have taken direct action through changes in the funding models to force universities to support economic development. In BC, the provincial government's B.C.'s Skills for Jobs Blueprint was released, pressing both universities and colleges to align their programming with labour market needs (Government of British Columbia, 2014). In Ontario, a discussion paper by the Ministry of Training, Colleges, and Universities (MTCU, 2012) and province-wide consultations with stakeholders led to the creation of the Strategic Mandate Agreements (SMAs) that require universities and colleges to make firm decisions on their industry sector alignments and programmatic focus (Newman, 2012). The intent of both the B.C.'s Skills for Jobs Blueprint and the SMAs was to align programming with the economy and labour market either by restricting operating grant allocations for specific high-demand programming or by making decisions on the types of programs and credentials offered.

As these changes in Canada's provincial higher-education systems proceed, there are very real risks of academic drift and institutional isomorphism, which can dilute the 
strengths of the existing system and result in unnecessary duplication of programs and mandates across the higher-education landscape. The challenge is to achieve the necessary reforms to that landscape while mitigating the risks. The existing literature suggests that this tension is particularly salient in the realms of research mandates, institutional culture, and system strategy, and this paper suggests important considerations for mitigating risk in these areas.

\section{Mitigating Risk: The Significance of Non-Traditional Research Mandates}

As Lepori and Kyvik (2010) noted in the European context, expectations that universities become more responsive to regional needs often meant that they came under pressure to deliver high-quality teaching and professional education of the sort formerly associated more exclusively with polytechnics, universities of applied science, and (in the Canadian context) colleges. The result was that a purely education-oriented mandate could no longer be used to differentiate traditionally research-oriented universities from other institutions, so "the research mission becomes then the strongest rationale for the binary divide in a time when the educational mission cannot be used for this purpose" (p. 314).

The European experience is instructive today. Whereas previously polytechnics, universities of applied sciences, universities of applied technology, colleges, and other institutions participated very little in what traditional universities would view as research, the vast number of students currently attending higher education outside of the traditional university environment means that governments are increasingly encouraging research in non-traditional contexts. This new research mandate for the non-traditional side of the binary divide has often resulted in faculty at traditional universities complaining that their research role is being encroached upon, threatening both their institutions' identities and their research funding (Griffioen \& de Jong, 2013, p. 174). In some cases-most notably in the United Kingdom (U.K.) and Australia-university academics' fears have come true: formerly non-university institutions have been granted "the same status as universities, including the right of awarding PhDs" (Lepori, 2008, p. 49). The U.K. has essentially moved from a binary to a unitary system (Lepori, 2008, p. 47; Lepori \& Kyvik, 2010, p. 296). Lepori (2008) stated that this change results in "a two-class system" (p. 49) in which institutions are all technically universities, but some have reputations as higher-tier or better institutions than others. The creation of second-class universities in a unitary system seems the worst-case outcome of unmitigated academic drift. Other jurisdictions are attempting to avoid this problem by preserving the distinction between systems in the binary divide through the definition and creation of parameters of research for the non-traditional sector.

Often, the definition of research for the non-traditional sector focuses on the concept applied research. This concept can encompass the two objectives Lepori and Kyvik (2010) identified for many universities of applied science as "regional knowledge providers and... [responsible for] improvement of the quality of professional education" (p. 296), the historic role of non-university institutions. An additional possibility for emphasis in nontraditional institutions is "innovation in the professional field" (Griffioen \& de Jong, 2013, p. 179) that is less strictly "scientific" (p. 179) than the research performed in traditional universities. On paper, this differentiation of research mandates appears to be a good 
solution for maintaining useful distinctions in a binary system and for avoiding the problem of creating second-class citizens in the university community, since non-traditional institutions can simultaneously improve their status and "accentuate...their differences from the traditional universities" (p. 174). The problem, however, is that this differentiation is much more difficult to achieve in practice, since it must work against faculty's "natural tendency...to follow the traditional patterns of scholarly activity associated with the research university" (Jones \& Gopaul, 2006), and since the differentiated mandate simply does not work for many subject domains. Furthermore, the differentiation must be maintained not only at the level of directing research, but also at the levels of institutional organization and assessment of achievement of research goals.

Setting aside research focused on improving educational delivery, it is reasonably easy to maintain a differentiated research mandate in some scientific fields, especially technology. However, for many other fields-such as the social sciences-there is no "workable distinction between basic and applied research" (Lepori, 2008, p. 54) because methodologies are the same for all forms of research. One possible solution to this problem appears to be encouraging research in specific fields in the non-traditional sector but not necessarily encouraging increased research across all possible subject domains. Alternatively, the traditional boundaries between fields can be usefully challenged by non-university research; Jones and Gopaul (2006) extended this conclusion from its original European context to Ontario's colleges, which they believed can productively focus on "research activities that tend to be problem-based, interdisciplinary, and rooted in questions of application and discovery that do not fit neatly within the boundaries of the traditional disciplines [in universities]" (para. 4).

Directing research in the non-traditional sector to the degree that seems necessary requires a proactive (rather than a reactive) government (Lepori \& Kyvik, 2010, p. 310) and institutional innovations to promote a research mandate that is markedly different from that of traditional universities. Jones and Gopaul (2006) cautioned that "in the absence of carefully defined objectives and explicit discussions of assessment, there will be a quite natural pull toward what many perceive to be the [traditional university] norm" (para. 8).

\section{Research Mandates and Differentiation: Examples of BC and Ontario Strategies}

A strong practical example of a non-university institution attempting to carve out a unique research mandate is found in the "research wheel" (Figure 1) developed by Fanshawe College (n.d.), a college of applied arts and technology (CAAT) located in London, Ontario. The intention of the research wheel is to visually guide faculty into non-traditional research channels and to help them conceptualize ways of integrating students into research, thus preserving the Ontario college's original focus on applied teaching.

The "scholarship" wedge of the wheel does include some university-style research aims, but the rest of the wheel encompasses perspectives on research that may not be as familiar to PhD-credentialled faculty who primarily conceptualize research in the same way as do traditional universities. Furthermore, the circular design visually counteracts the tendency in university cultures to treat disciplines and subdisciplines as silos, and thus supports Jones and Gopaul's (2006) call for an emphasis on interdisciplinarity as a differentiating factor in non-university research mandates. 


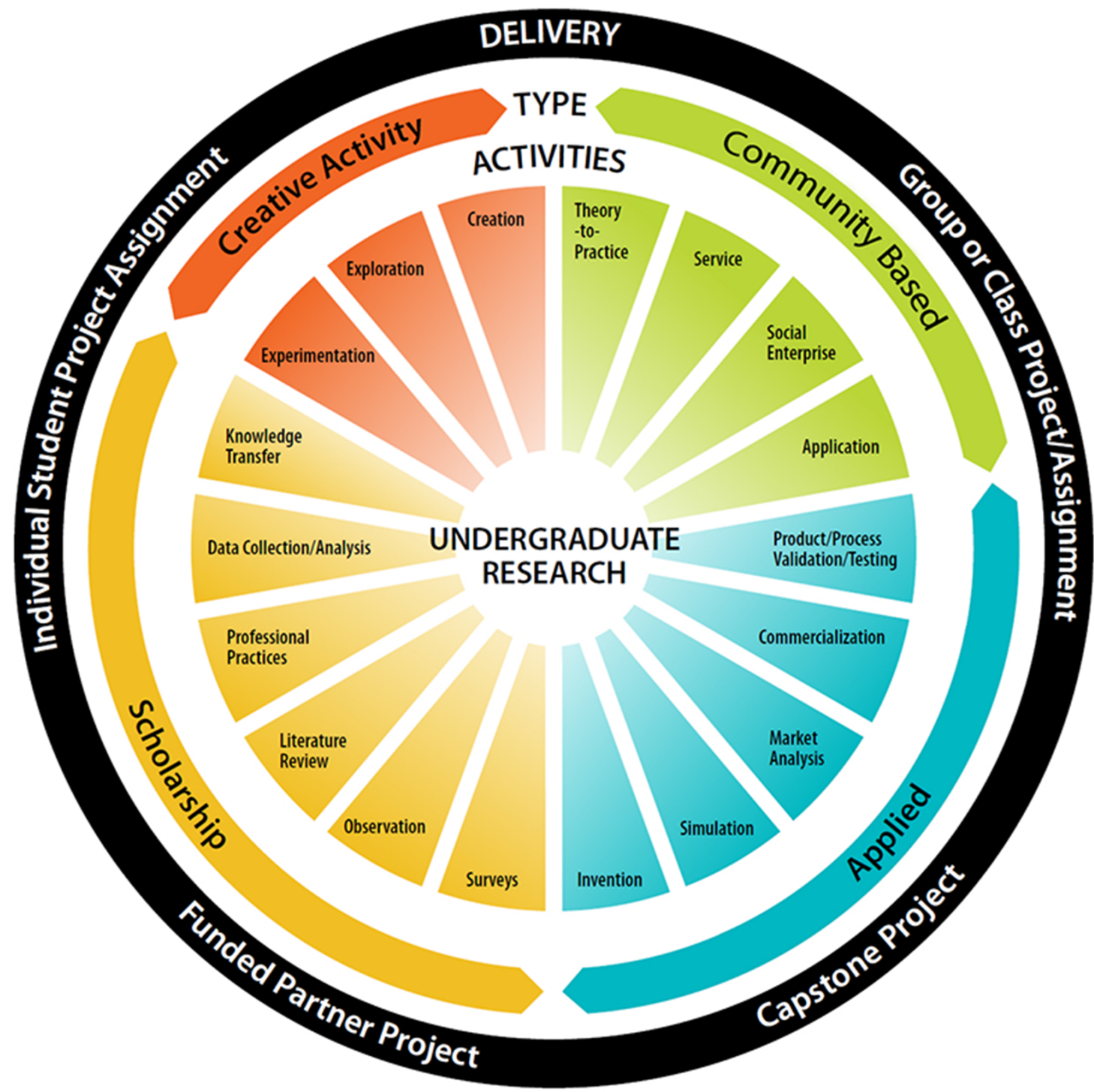

Figure 1. Fanshawe College's "research wheel." Adapted from Fanshawe College (n.d.). Copyright by Fanshawe College.

The research wheel is accompanied by both further definitions related to its wedges and specific curricular implementation examples. The suggested course-based applications range from the elementary to the extremely advanced, which is appropriate for a college that offers programming across widely disparate levels and fields. As just one example, the "invention" segment of the "applied" wedge offers the following suggestions for students' assignments:

- Invent their own health plan based on research principles

- Create a new technique/process for retouching a photo

- Survey contractors and industry players, and identify inefficiencies in process/ products-based on deficiencies, modify or improve existing building components

- Create a hydraulic pump test stand to verify the efficacy of a variety of motors and pumps. (Fanshawe College, n.d., http://reactr.ca/wheel/) 
These kinds of examples help faculty think outside of the traditional university box, and even the "scholarship" wedge includes student-oriented applied suggestions in the "observation" section. Fanshawe College has indicated its interest in significantly strengthening its research profile; as it moves forward toward this goal, tools such as the research wheel should help to mitigate the risks of academic drift.

The BC colleges have also become involved in applied research. The British Columbia Institute of Technology (BCIT) was an early adopter of applied research, adding it to its 1989 mandate (BCIT, 2014, p. 25). Since then, BCIT has continued to refine its definition of applied research, based on supporting provincial economic development by linking faculty and students with industry to solve specific problems. The expansion of BCIT's mandate to engage in applied research aligned with it receiving authority to confer applied baccalaureates in 1994 and applied master's degrees in 2003 (Dennison, 2006). BCIT's (2014) current definition of applied research is shown graphically in Figure 2.

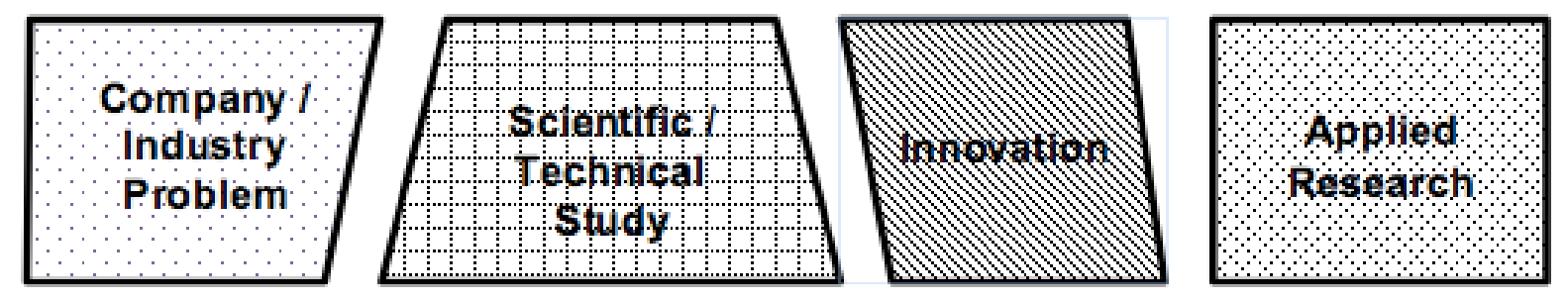

Figure 2. BCIT’s "What is applied research?” Adapted BCIT (2014, p. 3). Copyright 2014 by BCIT.

BCIT's approach to applied research has been consistent since 1989. It is focused on innovation-in-practice, which is working with existing knowledge to find solutions that keep business and industry competitive, as opposed to an innovation-in-knowledge approach, which is linked to basic research that typically occurs at universities.

Aside from the research universities and BCIT, applied research was not added as part of the role of BC colleges until the early 2000s, since the colleges were viewed primarily as teaching institutions. The shift toward adding applied research to their role occurred when such research started becoming part of the curriculum in courses and programs, which happened primarily when faculty decided to engage in some form of applied research to improve students' readiness for the labour market and to support local industry needs.

In the case of Camosun College, applied research was implemented in 2005 using a phased strategy, starting in a niche area as a "proof of concept" (Roemer, 2016, p. 5) and then expanding that capacity through the creation of additional research centres that are linked to program areas the college offers. Through this approach, the college has continued to increase its applied research capabilities, although it prefers the terms "innovation," "technology transfer", and "problem solving" to "applied research" (p. 5), since it sees research as being within the domain of the universities. Camosun's philosophy is that innovation is tied to providing students with an enhanced learning experience that "integrate[s] curriculum, research and industry" (p. 10) to better prepare them for the workforce. 
In its implementation of applied research, Langara College has taken a slightly different approach than Camosun, which reflects differences in programming between the two institutions. Langara's approach to applied research does not utilize research centres per se but rather has research embedded in the core academic (university transfer) components of those courses and programs under the guidance of the Office of Applied Research. Additionally, Langara's "strategic objectives of the Office of Applied Research" (Langara College, n.d., para. 3) are the following:

- To support business, industry, and community partners who are looking for practical solutions to a variety of issues

- To support innovation on campus and in the community

- To provide our students with exciting opportunities to engage in applied research with our faculty and partners

What fundamentally underlies or drives applied research at Langara is improving the students' "post-secondary education through experiential learning" (para. 4), which emphasizes that this activity is embedded within the curriculum and not conceptualized as a separate activity.

All four of these institutions are carefully and thoughtfully defining the scope and application of applied research in ways that allow them to increase their competitiveness without diluting their core focus or their positive differences from universities. Additionally, all four explicitly link applied research to community, industry, or experiential student learning, which should further guard against the potential negative consequences of academic drift by preserving a usefully distinct research mandate instead of simply duplicating traditional university approaches to research.

\section{Preserving Differentiation in Changing Contexts: Institutional Governance and Culture}

The how of first developing and then maintaining useful differentiation in the current post-secondary climate is also a question of governance at the system and institutional levels, both of which pose significant challenges. As Kohler (2006) observed, post-secondary institutions of all stripes have seen many grand plans evaporate with little real or lasting impact on the institutions themselves (p. 25).

Further complicating matters in Canada is the fact that it "is the only industrialized country without a federal office or department of education... [so] there is no clear mechanism for national policy development" (Shanahan \& Jones, 2007, p. 32). It is thus not possible to discuss system-level governance beyond the provincial level, and Ontario is further hampered by the fact that its government legislatively has little direct control over what traditional universities do (although the same is not as true of Ontario colleges; Clark et al., 2009). Important decisions-in Ontario in particular-are therefore being made at the institutional level.

Austin and Jones (2016) emphasized that the process of institutional governance is just as or perhaps more important than the governance model of the institution itself:

[Governance] is a process towards the end or towards the achievement of desired outcomes. And the end is legitimated through the process. Hence, legitimation through the correct process is the sine qua non of collegial governance, policy formulation, and decision-making in the academy. (pp. 149-150) 
This emphasis on collegiality has a long history in universities and will exist in nonuniversity institutions as well, since their faculty are often drawn from the university sector. The collegial approach is inefficient; however, the increasing prominence of what Austin and Jones called "a strong executive model" (p. 150) and what is often termed new public management risks alienating the many individuals whose inertia must be overcome. The new public management ship has sailed, and it is one that both European and North American institutions are "converging on...from different directions" (Usher, 2012, p. 22), largely due to the pressures of increasing massification and (in some jurisdictions, such as Ontario) extremely high system participation rates. However, as a 2006 Council of Europe conference on trends in academic governance concludes, one way to promote effective governance-regardless of the model used-is to emphasize both "transparency of structures and procedures" and "effective mechanisms of accountability of those involved in governance at various levels" (Vukasović, 2006, p. 209). It therefore seems that an institutional culture capable of adapting to the changing environment in positive differentiated ways must be one that values inclusivity of voices and transparency of process. This inclusivity appears possible under both older forms of governance and new public management versions.

One fascinating recent Dutch study concretely illustrates the importance of a culture of open consultative process in institutions and their governance structures. This study examined Dutch higher professional education institutions (roughly analogous to the Canadian college sector), which were undergoing a government-driven "change from teachingonly institutions to organizations of research and teaching" (Griffioen \& de Jong, 2015, p. 1). The study presumed that this would be a difficult cultural shift and hypothesized that implementing it at the level of individual faculty members would be positively and directly affected by those individuals' immediate managers, as previous research had suggested (Griffioen \& de Jong, 2015). However, the study reached a surprising conclusion: "The results show that the direct influence of the executive manager on the way [faculty] perceive new organizational aims is limited and primarily mediated through how organizational arrangements, such as collaborative decision-making processes, are perceived” (p. 14).

Griffioen and de Jong (2015) recommended further study in this new direction. In other words, the emphasis on process and transparency that both Austin and Jones (2016) and the Council of Europe conference on governance (Vukasović, 2006) identified is perhaps more crucial than individual managers' traits in the context of major institutional change. Canadian post-secondary institutions currently undergoing similar changes should take note.

Furthermore, both the university and non-university sectors must combat a further impediment to useful institutional and cultural change: faculty disengagement and ignorance. There is a significant amount of research that demonstrates the increasing trend toward disengagement in academic senates in universities; similar problems exist with governance and steering bodies in non-universities. As Jones (2012) observed in a discussion of a study of Canadian senates:

It is surprising how many faculty members actually don't know very much about academic governance, about the traditions of the university, or [about] a sense of ownership in the academic decision-making process that hasn't been part of their doctoral student experience. (p. 11) 
Elwood and Rainnie (2012) identified a similar problem impeding strategic planning in the Irish Institutes of Technology (in some ways analogous to the Canadian non-university sector) as being "low levels of awareness of the existence of a strategic plan or its contents" (p. 115). Disengagement, which further hinders effective strategic planning and change, may be in part due to a perception that bodies such as senates do not, in fact, accomplish anything of note, as Jones (2012) hypothesized. An institutional culture that values consultation, combined with a simple effort to inform and teach faculty about strategic plans and processes, may go a long way toward combating faculty inertia (which could likely be the most significant obstacle to meaningful institutional change).

\section{The Risk of Institutional Isomorphism}

Van Vught (1996) examined the challenges of useful differentiation and academic drift through the lens of institutional isomorphism, which he characterized as "a constraining process that forces organizations to resemble other organizations" (p. 45). His argument was that all forms of isomorphism result in de-differentiation, a drive toward sameness, and he concluded that increasing de-differentiation is caused by "the combination of strict and uniform governmental policies and the predominance of academic norms and values" (p. 56). All higher-education institutions face the same constraints around funding, enrolments, and a desire by governments to have them support economic development. This results in the same behaviours used to address funding shortages, become more entrepreneurial, recruit more international students, and offer a broad range of academic programs and credentials through the replication of similar strategies. Skolnik (2010) noted that this problem is particularly pronounced in Ontario universities, which "have [all] embraced the research-university model, the highest-cost model for a post-secondary institution. Thus, almost all Ontario students who pursue a bachelor of arts or a bachelor of science do so in the highest-cost type of post-secondary institution" (p. 13). However, these universities are also encouraged by governments to offer more vocationally relevant skills-based programming, whether through continuing or professional studies, and thus end up offering programming similar to that of the colleges (Jones, 2009).

\section{Isomorphism in Ontario's Strategic Mandate Agreements}

At both the institutional and system levels, strategic documents are vitally important for supporting productive differentiation. In 2012, the Ontario provincial government created the Strategic Mandate Agreements (SMAs) to force universities and colleges to make decisions on their specific industry sector alignments and programmatic focus (Newman, 2012), which, in theory, should have more clearly articulated differentiation among higher-education institutions, including both universities and colleges (Ontario Confederation of University Faculty Association [OCUFA], 2014b). The current iteration of the SMAs may not, however, succeed in fulfilling their purposes; the OCUFA (2014a), for instance, complained that the universities' SMAs are far too general in some areas and can be very slight on metrics. A more significant problem is isomorphic responses to the SMA exercise.

An interesting group of SMAs to examine in this context is the group of Ontario colleges that were designated Institutes of Technology and Advanced Learning (ITALs), which means that they can offer a greater percentage of degree programming than the other 
Colleges of Applied Arts and Technology (CAATs; Clark et al., 2009, pp. 153-154). Colleges with the ITAL designation seem more at risk than CAATs for problems associated with academic drift and institutional isomorphism, due to their more meaningful ability to compete with universities in offering bachelor degrees. There are only five ITALs in Ontario: Conestoga, Humber, Sheridan, George Brown, and Seneca (p. 154). Sheridan's blunt SMA statement that its guiding vision is "to become Sheridan University" (Ministry of Training, Colleges and Universities [MTCU], 2014g, p. 2) is an example of potential drift; hence, it is most productive for this article's purposes to focus on the other four ITALs. Both Conestoga and Humber express essentially the same vision statement: Conestoga's is "Recognition for excellence in polytechnic education" (MTCU, 2014b, p. 2), and Humber's is "Leadership in polytechnic education" (MTCU, 2014d, p. 2). In contrast, it is interesting to note that Ryerson University has omitted its historical status as a polytechnic from its SMA and, instead, rebrands itself as a "comprehensive innovation university" (MTCU, 2014e, p. 3). This material comes from the vision, mission, and key areas of differentiation in the SMAs, which should represent the unique characteristics and directions of the institutions generally, and from which the rest of the documents follow in more detail. Other common themes in these guiding statements for the ITALs (excluding Sheridan) include emphases on skilled employment and innovation, empowering students, and excellence in education.

Under the theme of skilled employment and innovation: Conestoga's mission is "to champion innovation and excellence in career-focused education, training and applied research" (MTCU, 2014b, p. 2); George Brown's vision is to "build a seamless bridge between learners and employment as we develop dynamic programs and workplace-ready graduates who will be the candidates of choice for employers" (MTCU, 2014c, p. 2); Humber's mission is developing "highly skilled...adaptable citizens [who are] successful in careers" (MTCU, 2014d, p. 2); and Seneca's vision is that "We are driven by our values of excellence, [and] innovation" (MTCU, 2014f, p. 2).

In the theme of empowering students: Conestoga's mission is "to inspire students and employees to strive towards their highest potential” (MTCU, 2014b, p. 2); George Brown's vision is to "create a community of lifelong learners" (MTCU, 2014c, p. 2); Humber's mission is to develop "broadly educated, highly skilled, and adaptable citizens to be successful in careers" (MTCU, 2014d, p. 2); and Seneca's vision is "building a different kind of school with a different kind of graduate...highly attractive to employers; ethical, engaged and confident; and adaptable and capable of addressing the challenges of the future in a global context" (MTCU, 2014f, p. 2).

Under excellence in education: Conestoga's mission is "to champion innovation and excellence in career-focused education" (MTCU, 2014b, p. 2); George Brown has a vision of "set[ting] the benchmark to which all colleges will aspire" (MTCU, 2014c, p. 2); Humber's vision is "leadership in polytechnic education" (MTCU, 2014d, p. 2); and Seneca's vision is of "building a different kind of school.... Every program at Seneca will embed cross-disciplinary and experiential learning, and provide flexible learning options" (MTCU, 2014f, p. 2).

The two ITALs that explicitly discuss research in their opening sections-George Brown and Seneca-are careful to qualify it as "applied" (MTCU, 2014c, p. 3; MTCU, 2014f, p. 3). Additionally, while significantly overlapping across the ITALs themselves, these claims 
and descriptors are also reproduced in some of the SMAs of Ontario universities that are not generally known for their prominent research profiles, such as Brock University, Trent University, and the University of Windsor.

For example, under skilled employment and innovation Brock University's key areas of differentiation are "a special focus on transdisciplinary research hubs highlighting areas of strength that contribute to the social, economic and cultural development of the Niagara Region" (MTCU, 2014a, p. 3). Trent University's vision is "affirm[ing] our commitment to excellence, to innovation and to leadership in research, academic programmes and community partnerships" (MTCU, 2014h, p. 2). The University of Windsor's "supports the economic and cultural development of its region... with a comprehensive range of programs, while focusing its research activity to respond directly to regional priorities" (MTCU, 2014i, p. 3).

Empowering students is described by Brock University as being "a dynamic postsecondary educational institution that...makes a difference in the lives of individuals in our Brock community, the Niagara Region, Canada, and the world" (MTCU, 2014a, p. 2). Trent University "creates opportunities for students, staff and faculty to flourish and develop as individuals and as global citizens" (MTCU, 2014h, p. 2). The University of Windsor aims to enable "people to make a better world through education, scholarship, research, and engagement" (MTCU, 2014i, p. 2).

Related to excellence in education: Brock University "demonstrates leadership and innovation in teaching and learning across disciplines" (MTCU, 2014a, p. 2). Trent University "encourage[s] and celebrate[s] excellence and innovation in teaching, learning, research, and student development" (MTCU, 2014h, p. 2). The University of Windsor envisions "a progressive, student-centred university, where the challenges of communities and of a world in transition inform the education" (MTCU, 2014i, p. 2).

Clearly, there is very little meaningful differentiation and a great deal of isomorphism among the SMAs of these institutions, whether ITALs or full universities; particularly problematic are the universities' emphases on regional economic development, which is traditionally the purview of colleges (including the ITALs), and the similarities between the remainder of the ITALs' emphases and those of the universities. While the SMAs are all scheduled for revision in 2017, it remains to be seen whether they will more effectively support differentiation. They actually represent a significant opportunity to work against de-differentiation, which is in all stakeholders' interests, and can act as a powerful tool for positive change. The one challenge is to make sure that, while all Ontario institutions go through the same exercise of creating an SMA, this similarity in process does not produce isomorphism in products.

\section{Conclusion}

It is apparent that while Canada is not as far along as the U.K. on the path toward a unitary post-secondary system, there is a blurring underway in the distinction between colleges and universities. Provincial governments are actively reshaping their post-secondary systems. In most cases, the intervention appears to align post-secondary institutions with national or regional economic needs, but other reasons for intervention include increasing access, streamlining degree completion, and responding to community pressure to have a university. However, these changes are not simple, and there are costs 
associated with implementing them that range from reputation to institutional culture or market positioning. The problem of academic drift looms across both sectors as a very substantial source of inefficiency, due to de-differentiation. These practical issues and costs are not always part of the calculation when governments tinker with the universities and colleges, although they desperately need to be.

One significant method of counteracting the negative effects of academic drift and institutional isomorphism is to ensure that research mandates for the non-university sector encourage specific kinds of applied and/or interdisciplinary research in fields in which this work is unlikely to simply duplicate that of traditional universities. This encouragement, however, requires working against the tendency of $\mathrm{PhD}$-credentialled faculty toward replicating existing university research approaches, and therefore means that institutions will need to design strong directions and assessments to support a differentiated research mandate. Additionally, important system-level steering documents (such as the Strategic Mandate Agreements in Ontario) need to robustly support this differentiated mandate.

Finally, institutional governance is an important consideration for preserving useful differentiation in an increasingly changing environment. The model of governance that the institution adopts may be less significant than the perception of openness of process that the institution fosters. Faculty perceptions of transparency and knowledge of the importance of research mandates in the changing system context will ultimately support positive changes in institutional priorities and differentiation within Canadian highereducation systems.

\section{Notes}

1. Defined by Griffioen and de Jong (2013) as the "academisation processes of non-university educational institutions" (p. 173).

2. Kohler (2006) attributes this institutional resistance to the fact that the institutions deliberately recruit critical and independent minds, for obvious reasons.

3. Although all Ontario universities are, technically, equally all research universities by legislation, in the words of Orwell (1946), "some...are more equal than others" (p. 123). There is a substantial gulf between, on the one hand, the research profiles of the University of Toronto, Western University (the University of Western Ontario), Queen's University, and the University of Waterloo, and, on the other hand, many other Ontario universities.

\section{References}

Austin, I., \& Jones, G. (2016). Governance of higher education: Global perspectives, theories, and practices. New York, NY: Routledge.

British Columbia Institute of Technology (BCIT). (2014). Applied research at BCIT: Solving real world problems for industry. Burnaby, BC: Author. Retrieved from http:// www.bcit.ca/files/appliedresearch/pdf/applied_research_publication.pdf

Clark, I. D., Moran, G., Skolnik, M. L., \& Trick, D. (2009). Academic transformation: The forces reshaping higher education in Ontario (Queen's Policy Studies Series). Montreal, QC: McGill-Queen's University Press. 
College and Institute Act, Revised Statues of British Columbia (1996, c. 52). Retrieved from http://www.bclaws.ca/civix/document/id/complete/statreg/96052_01

Dennison, J. D. (1995). Community college development in Canada since 1985. In J. D. Dennison (Ed.), Challenge and opportunity: Canada's community colleges at the crossroads (pp. 13-104). Vancouver, BC: University of British Columbia Press.

Dennison, J. D. (2006). From community college to university: A personal commentary on the evolution of an institution. Canadian Journal of Higher Education, 36(2), 107-124.

Dennison, J. D., \& Schuetze, H. G. (2004). Extending access, choice, and the reign of the market: Higher education reforms in British Columbia, 1989-2004. The Canadian Journal of Higher Education, 34(3), 13-38.

Elwood, L., \& Rainnie, A. (2012). Strategic planning in Ireland's institutes oftechnology. Higher Education Policy, 25(1), 107-129.

Fanshawe College. (n.d.). Research at Fanshawe College. Retrieved from https://www. fanshawec.ca/teaching-and-learning/professional-development/research-fanshawecollege

Fisher, D., Rubenson, K., Lee, J., Clift, R., MacIvor, M., \& Meredith, J. (2014). The transformation of the PSE system in British Columbia. In D. Fisher, K. Rubenson, T. Shanahan, \& C. Trottier (Eds.), The development of postsecondary education systems in Canada: A comparison between British Columbia, Ontario, and Québec, 1980-2010 (pp. 35-121). Montreal, QC: McGill-Queen's University Press.

Government ofBritish Columbia.(2014).B.C.'s skillsforjobs blueprint: Re-engineering education and training. Retrieved from https://www.workbc.ca/getmedia/4c54646a93fa-4566-b148-f43a3f27b240/Booklet_BCsBlueprint_web_140428.pdf.aspx

Griffioen, D. M. E., \& de Jong, U. (2013). Academic drift in Dutch non-university higher education evaluated: A staff perspective. Higher Education Policy, 26(2), 173-191. doi:10.1057/hep.2012.24

Griffioen, D. M. E., \& de Jong, U. (2015). The influence of direct executive managers on lecturers' perceptions on new organizational aims in times of academic drift. International Journal of Leadership in Education, 20(4), 1-17. doi:10.1080/13603124.2015.1066867

Hogan, B., \& Trotter, L. (2013). Academic freedom in Canadian higher education: Universities, colleges and institutes were not created equal. Canadian Journal of Higher Education, 43(2), 68-84.

Jones, G. (1997). Higher education in Ontario. In J. A. Jones (Ed.), Higher education in Canada: Different systems, different perspectives (pp. 137-159). New York, NY: Garland Publishing.

Jones, G. (2009). Sectors, institutional types and the challenges of shifting categories: A Canadian commentary. Higher Education Quarterly, 63(4), 371-383.

Jones, G. (2012). Trends in academic governance in Canada. In R. Kool (Ed.), Academic Governance 3.o: What could it be? How can we get there? (pp. 6-12). Vancouver, BC: Confederation of Faculty Associations of British Columbia. Retrieved from http://www. cufa.bc.ca/wp-content/uploads/2015/10/Academic-Governance-3.o.pdf 
Jones, G., \& Gopaul, B. (2006, March). Research and the polytechnic. College Quarterly, 9(3). Retrieved from http://collegequarterly.ca/2006-volo9-numo3-summer/jones.html

Kohler, J. (2006). Higher education governance: Background, significance and purpose. In J. Kohler \& S. Huber (Eds.), Higher education governance between democratic culture, academic aspirations and market forces (pp. 17-32). Strasbourg, France: Council of Europe. Retrieved from http://www.coe.int/t/dg4/highereducation/ Resources/Higher\%20educationgovernance\%20impo.pdf

Langara College. (n.d.). About Langara: Applied research. Retrieved from http:// langara.ca/about-langara/applied-research/index.html

Lepori, B. (2008). Research in non-university higher education institutions: The case of the Swiss universities of applied science. Higher Education, 56(1), 45-58.

Lepori, B., \& Kyvik, S. (2010). The research mission of universities of applied science and the future configuration of higher education systems in Europe. Higher Education Policy, 23(3), 295-316.

MacDonald, J. (1962). Higher education in British Columbia and a plan for the future. Vancouver, BC: University of British Columbia Press.

Marginson, S. (2002). Nation-building universities in a global environment: The case of Australia. Higher Education, 43(3), 409-428.

Marshall, D. (2004). Degree accreditation in Canada. The Canadian Journal of Higher Education, 34(2), 69-96.

Marshall, D. (2008). Differentiation by degrees: System design and the changing undergraduate environment in Canada. The Canadian Journal of Higher Education, $38(3), 1-20$.

Ministry of Training, Colleges and Universities (MTCU). (2012). Strengthening Ontario's centres of creativity, innovation and knowledge: A discussion paper on innovation to make our university and college system stronger. Toronto, ON: Government of Ontario.

Ministry of Training, Colleges and Universities (MTCU). (2014a). 2014-17 Strategic mandate agreement: Brock University. Retrieved from https://www.ontario.ca/page/ college-and-university-strategic-mandate-agreements

Ministry of Training, Colleges and Universities (MTCU). (2014b). 2014-17 Strategic mandate agreement: Conestoga College Institute of Technology and Advanced Learning . Retrieved from https://www.ontario.ca/page/college-and-university-strategic-mandateagreements

Ministry of Training, Colleges and Universities (MTCU). (2014c). Strategic mandate agreement: George Brown College of Applied Arts and Technology. Retrieved from https://www.ontario.ca/page/college-and-university-strategic-mandate-agreements

Ministry of Training, Colleges and Universities (MTCU). (2014d). Strategic mandate agreement: Humber College Institute of Technology and Advanced Learning. Retrieved from https://www.ontario.ca/page/college-and-university-strategic-mandateagreements 
Ministry of Training, Colleges and Universities (MTCU). (2014e). Strategic mandate agreement: Ryerson University. Retrieved from https://www.ontario.ca/page/collegeand-university-strategic-mandate-agreements

Ministry of Training, Colleges and Universities (MTCU). (2014f). Strategic mandate agreement: Seneca College of Applied Arts and Technology. Retrieved from https:// www.ontario.ca/page/college-and-university-strategic-mandate-agreements

Ministry of Training, Colleges and Universities (MTCU). (2014g). Strategic mandate agreement: Sheridan College Institute of Technology and Advanced Learning. Retrieved from https://www.ontario.ca/page/college-and-university-strategic-mandate-agreements

Ministry of Training, Colleges and Universities (MTCU). (2014h). Strategic mandate agreement: Trent University. Retrieved from https://www.ontario.ca/page/college-anduniversity-strategic-mandate-agreements

Ministry of Training, Colleges and Universities (MTCU). (2014i). Strategic mandate agreement: University of Windsor. Retrieved from https://www.ontario.ca/page/ college-and-university-strategic-mandate-agreements

Newman, D. (2012, August 7). Subject: Mandate agreements submissions (Memo sent to executive heads and presidents, universities presidents, colleges). Toronto, ON: Ontario Ministry of Training, Colleges and Universities.

Ontario Colleges of Applied Arts and Technology Act, Statutes of Ontario (2002, c. 8, Sched. F). Retrieved from https://www.ontario.ca/laws/statute/o2008f

Ontario Confederation of University Faculty Association (OCUFA). (2014a). OCUFA policy statement on university differentiation in Ontario: May 2014. Retrieved from https://ocufa.on.ca/assets/OCUFA-Policy-Statement-on-Differentiation-20140216.pdf

Ontario Confederation of University Faculty Association (OCUFA). (2014b, November 14). OCUFA releases policy statement on differentiation, analysis of SMAs. Retrieved from https://ocufa.on.ca/blog-posts/universities-blog-posts/ocufa-releases-policy-statementon-differentiation-analysis-of-smas

Orwell, G. (1946). Animal farm. New York, NY: Harcourt Brace Jovanovich.

Plant, G. (2007, April). Campus2020: Thinking ahead: The report (Report No. C2007-960088-3). Retrieved from https://www.scribd.com/document/96969732/ British-Columbia-Campus-2020-Thinking-Ahead-The-Report-Access-Excellence-TheCampus-2020-Plan-for-British-Columbia-s-Post-Secondary-Education

Post-secondary Education Choice and Excellence Act, Statutes of Ontario (2000, c. 36). Retrieved from https://www.ontario.ca/laws/statute/oop36?search=post+seconda ry+choice+in+excellence

Roemer, T. (2016, January). Innovation as a catalyst for job preparedness: Benefits of college-based innovation for students, curriculum and regional economic development. Victoria, BC: Camosun College.

Shanahan, T., \& Jones, G. (2007). Shifting roles and approaches: Government coordination of post-secondary education in Canada, 1995-2006. Higher Education Research \& Development, 26(1), 31-43. 
Skolnik, M. L. (2006). Some thoughts on the meaning of and values that influence degree recognition in Canada. College Quarterly, 9(4), 1-10.

Skolnik, M. L. (2010). A look back at the decision on the transfer function at the founding of Ontario's colleges of applied arts and technology. Canadian Journal of Higher Education, 4O(2), 1-17.

Usher, J. M. (2012). Academic governance 3.0: Past, present and future. Academic Governance 3.o: What could it be? How can we get there? (pp. 20-25). Vancouver, BC: Confederation of University Faculty Associations of British Columbia. Retrieved from http://www.cufa.bc.ca/wp-content/uploads/2015/10/Academic-Governance-3.o.pdf

Van Vught, F. (1996). Isomorphism in higher education? Towards a theory of differentiation and diversity in higher education systems. In V. L. Meek, L. Goedegebuure, O. Kivinen, \& R. Rinne (Eds.), The mockers and mocked: Comparative perspectives on differentiation, convergence and diversity in higher education (pp. 42-60). Oxford, England: Pergamon Press.

Vukasović, M. (2006). General report. In J. Kohler \& S. Huber (Eds.), Higher education governance between democratic culture, academic aspirations and market forces (pp. 203-212). Strasbourg, France: Council of Europe. Retrieved from http://www.coe.int/t/ dg4/highereducation/Resources/Higher\%20educationgovernance\%20impo.pdf

\section{Contact Information}

Lane D. Trotter

Office of the President

Langara College

ltrotter@langara.ca

Lane Trotter joined Langara College as its third president in January of 2014. His career in higher education spans 24 years, including previous roles as Senior Vice President, Academic at Fanshawe College, and Dean, at both British Columbia Institute of Technology (BCIT) and St. Clair College. Dr. Trotter's research interests include governance and accountability in post-secondary institutions, academic freedom, and comparative higher education. He served as the Chair of the Council of Presidents of $\mathrm{BC}$ Colleges between 2015 to 2017. He earned his Doctorate of Education from Simon Fraser University (2010) and holds a MPA (1992) from the University of Victoria.

Amy D. Mitchell is a professor in the School of Language and Liberal Studies at Fanshawe College in London, Ontario. She holds a BA (Honours) in English and Creative Writing from the University of Windsor and an MA and PhD in English Literature from the University of Western Ontario. She has participated in several projects related to student mobility at Fanshawe College and acted as principal author for the related reports to both the College-University Consortium Council and Colleges Ontario. 